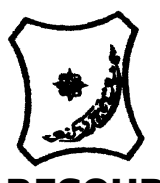

Bayero Journal of Pure and Applied Sciences, 11(1): 86 - 90

Received: January, 2018

Accepted: April, 2018

ISSN $2006-6996$

\title{
RESOURCE USE EFFICIENCY OF SMALL SCALE POULTRY EGG PRODUCTION IN YOLA NORTH AND YOLA SOUTH LOCAL GOVERNMENT AREAS OF ADAMAWA STATE, NIGERIA
}

\author{
Lawal, $\mathbf{H}^{\mathbf{1}}$. and Alfred, $\mathrm{B}^{\mathbf{2}}$. \\ Department of Agricultural Economics and Extension, Modibbo Adama University of Technology, P.M.B \\ 2076, Yola, Adamawa State, Nigeria \\ Corresponding author elharunyl@yahoo.co.uk
}

\begin{abstract}
This study analyse resource use efficiency of small scale poultry egg production in Yola North Local Government Area of Adamawa State, Nigeria. The objective of this study is to determine if resources are efficiently utilized in small scale poultry egg production in the study area. A total of one hundred respondents were randomly selected for this study. The data collected were analysed using both descriptive and inferential statistics. The results revealed that the coefficient of determination $\left(R^{2}\right)$ was $96.33 \%$. The overall model was highly significant at $1 \%$ level of probability as shown by the magnitude of the F-statistics. The coefficient of flock size was positive $(0.5794)$ and statistically highly significant at $1 \%$ level of probability. The positive coefficient implied that on the average, a $1 \%$ increase in the number of birds will increase poultry egg production by about $57.94 \%$. Findings from the study indicated that flock size $X 1$ was under utilized since the ratio obtained is greater than unity. The results showed that poultry egg farmers in the study area are not efficient in their production as regards the four important resources (flock size, feeds, family and hired labour) that were used in this analysis. One important point to note is that of all the resources, none has a negative MVP signifying that these farmers are still producing within economically rational range. The study recommends that poultry egg industry in the study area should be reorganized in such a way that labour input is used only for the necessary activities. Also, increasing the number of birds per flock and feeding rate with high quality feed can improve the resource use efficiency of the poultry egg farmers in the study area.

Key words: Efficiency, Flock size, Poultry egg.
\end{abstract}

\section{INTRODUCTION}

Poultry production in the past was not recognized as an important occupation but it has developed and occupies a place of pride among the livestock enterprises due to its rapid monetary turnover (Adepoju, 2008).The enterprise had become a diverse industry with variety of business interests such as egg production, broiler production, hatchery and poultry equipment business (Adebayo et al. 2015). The importance of poultry sub-sector is mainly in the provision of meat, egg, provision of employment opportunities to the active population as well as the contribution to revenue generation (Afolabi et al., 2013). Global egg production is growing rapidly especially in Asia (59.11\%), America (20.86\%) and Europe $(14.82 \%)$ with Africa having only $5.16 \%$, while Australia and Oceania stood at $0.03 \%$ and $0.02 \%$ respectively (FAO, 2016).Nigeria hosts $69.83 \%$ of poultry egg production in West Africa, with an estimated population of 72.4 million chickens. This is followed by Burkina Faso and Ghana which recorded $6.42 \%$ and $5.01 \%$ respectively (Adeyemo and OniKoyi, 2012; FAO, 2016).

The consumption of animal protein in Nigeria is inadequate in the diet of most households and stood at below 8gm per caput per day. This is below the FAO minimum intake of protein of $65 \mathrm{gm}$ by an average person per day; out of which, $36 \mathrm{gm}$ should come from animal sources (Yusuf and Malomo, 2007; Nsikak-Abasi et al., 2013). As a result of the protein deficit, extensive hunger and malnutrition are apparent in the country. The country's poultry industry is dominated by small-holder farmers who on the aggregate raise bulk of the birds for egg and meat production, but individually rear less than 1,000 birds using different production strategies and this could be one of the reasons why the country has not been able to meet the protein needs of the populace which leads to the massive importation of poultry products in an attempt to bridge the gap between demand and supply (MANR, 2008; Adeyemo and Onikoyi, 2012). The low per caput animal protein intake may be as a result of inefficient resource utilization by the farmers. This is because the future of the industry depends on the ability of the farmers to produce more efficiently, thereby reducing the unit cost of production and ensuring higher profitability in the enterprise (Dama et al.,2002).

In order to achieve optimum production and meet the basic minimum of the dietary needs of Nigerians, determining resource use efficiency of small scale poultry egg production is necessary for policy purposes as this can help to ascertain over utilization or other wise of the factor inputs. 
Bajopas Volume 11 Number 1 June, 2018

In an economy where technologies are absent, efficiency studies reveal the prospect of increasing output by improving efficiency without raising the level of resources. The findings will go a long way in bridging some knowledge gaps and aid in formulating policies aimed at ensuring an increase and more profitable small holder poultry egg production in Nigeria.

\section{METHODOLOGY \\ Study Area}

The study was conducted in Yola metropolis of Adamawa State, Nigeria. The study area lies between latitude $9014^{\prime} \mathrm{N}$ and longitude $12028^{\prime} \mathrm{E}$. The city comprises of Jimeta which is the administrative and commercial Centre, and the ancient Yola town. It is located within the tropical climate and covers a land area of about $20,181 \mathrm{~km}$ with an annual rainfall of less than 1,000mm (Adebayo and Tukur, 1999). Agriculture remains the major occupation of the inhabitants. Crops such as rice, maize, guinea corn, millet and beans are produced while cattle rearing; fish farming and Poultry keeping are also practiced by the inhabitants.

\section{Sampling and Data Collection Procedure}

The sampling procedure involved Snow ball sampling. This technique was used to locate all the poultry farmers in the area. A total sample size of 120 farms were located through referral process and then, 100 farmers were randomly selected from the sample size in order to form the sample frame of the study. About 100 questionnaires were administered to them face to face in their farm centers with the aid of trained enumerators, but only 91 were correctly filled, retrieved and used for the analysis. The primary data collected on inputs include farm size/number of birds, family labour, hired labour feeds and medication, rearing experience, farmers' age, transportation cost and litres of water used.

\section{Analytical Techniques}

Ordinary least square (OLS) model using CobbDouglas production function was used to determine the relationship between inputs and output used in poultry egg production (Ahmed and Egwuma, 2015).The model is explicitly specified below:

$\ln Y=\ln \beta_{o}+\beta_{1} \ln X_{1}+\beta_{2} \ln X_{2}+\beta_{3} \ln X_{3}+\beta_{4} \ln X_{4}+\ldots+\beta_{9} X_{9}+\mu_{i}$ (1)

Where:

$$
\begin{aligned}
& Y=\text { Output (number of crates) } \\
& X_{1}=\text { Flock size (number of birds) } \\
& X_{2}=\text { Medication (\#) } \\
& X_{3}=\text { Feeds (kg) } \\
& X_{4}=\text { Hired labour (man-day) } \\
& X_{5}=\text { Family labour (man-day) } \\
& X_{6}=\text { Farmer's age (years) } \\
& X_{7}=\text { Rearing experience (years) } \\
& X_{8}=\text { Water (liters) } \\
& X_{9}=\text { Transportation cost (\#) } \\
& \mu_{i}=\text { Error term }
\end{aligned}
$$

$\beta_{o}=$ Constant term

$\beta_{1}-\beta_{9}=$ Estimated parameters

\section{Marginal Analysis of Input Utilization}

The marginal analysis of input utilization was used to estimate the resource use efficiency in poultry egg production (Alimi, 2000). This is mathematically expressed as:

$r=\frac{M V P}{M F C}$

Where:

$M V P=$ Marginal value product of each input

$M F C=$ Marginal factor cost of each input

$r=$ Efficiency ratio

The values of $M V P$ and $M F C$ for this study were estimated as follows;

$M P P=\frac{\beta_{i} Y}{X_{i}}$

$M V P=M P P X_{i} \times P_{y}$

$M F C=P_{y}$

Where:

$Y=$ Arithmetic mean value of poultry egg output

$\beta_{i}=$ Regression coefficient of the $i^{\text {th }}$ input

$X_{i}=$ Arithmetic mean value of the $i^{\text {th }}$ input considered

$P_{y}=$ Market price of the $i^{t h}$ input

When the ratio is less than one $($ i.e. $r<1)$, it shows over utilization of the input under consideration. This implies that a decrease in the use of that input will increase farmers profit level. When the ratio is greater than one (i.e. $r>1$ ), it indicates that the input in question is under utilized. Thus, the rate of use of that input will increase the profit level accrued to the farmers. However, when the ratio is equal to one (i.e. $r=1$ ), it shows that the resource is efficiently utilized during the production process and this is the best point of profit maximization.

\section{RESULTS AND DISCUSSION \\ Production Function Analysis}

The modern theory of efficiency dates back to the pioneering work of Farrell (1957) who defined efficiency of a firm as its ability to produce the largest possible quantity of output from a given set of inputs. Farmers in general, have to use available inputs as efficiently as possible to achieve optimum production (Udoh and Akintola, 2001; Etim et al., 2005). Thus, efficient allocations of available resources by the farmers do affect production. Ashagidigbi et al. (2011) studied the determinants of efficiency among poultry egg farmers in Plateau State, Nigeria. 
The results show that a mean technical efficiency of poultry egg farmers was $94.2 \%$ and that output intensity, utility cost, capital input, average cost of feeds and drugs were the determinants of allocative efficiency whereas access to credit and farming experience had significant impact on cost inefficiency. In order to determine the relationship between variable inputs and output in poultry egg production in the study area, number of eggs obtained in poultry farm by farmers was regressed against some explanatory variables such as farmers' age, experience in poultry rearing, flock size, medication, feed, family labour, hired labour, transportation cost and liters of water used.

Analysis of the result in Table1 revealed that the coefficient of determination $\left(R^{2}\right)$ was 0.9633 which indicated that about $96.33 \%$ of the variation in the dependent variable has been explained by the independent variables included in the model and only $3.67 \%$ of the variation was accounted for by error term. The estimated coefficients of flock size $\left(X_{1}\right)$, medication $\left(X_{2}\right)$, feeds $\left(X_{3}\right)$, hired labour $\left(X_{4}\right)$, family labour $\left(X_{5}\right)$, farmer's rearing experience $\left(X_{6}\right)$ were all positive and statistically significant at varying levels of probability. This showed that an increase in the units of these variables will bring about increase in the total eggs output of the farmers. The coefficients of farmer's age $\left(X_{7}\right)$ and Quantity of water $\left(X_{8}\right)$ though positive, but was not statistically significant at the respective probability levels. Moreover, the coefficient of transportation cost $\left(X_{9}\right)$ was negative and statistically insignificant. The overall model is significant at $1 \%$ level of probability as shown by the magnitude of the F-statistics. This is an indication of a goodness of fit and that the independent variables jointly influenced the number of poultry egg production.
The coefficient of flock size was positive (0.5794) and statistically significant at $1 \%$ level of probability. The positive coefficient implied that on the average, a $1 \%$ increase in the number of birds will increase poultry egg production by about $57.94 \%$. Therefore, egg output increases with increase in the number of birds reared. Feed variable also has a positive coefficient (0.3118) and is statistically significant at $1 \%$ level. This indicated that increasing the quantity of feeds supplied to the birds by $1 \%$ ceteris paribus, will lead to an increase in the eventual egg output by about $31.18 \%$. Thus, both quantity and quality of feeds supplied to the poultry birds helps to improve their size and the number of eggs produced as well as the income obtained the farmers.

The coefficient of medication is positive and statistically significant at $1 \%$ level. This implied that a $1 \%$ change in the amount spent on drugs will increase poultry egg output by $30.05 \%$ with other factors held constant. The results also, showed that rearing experience is positive and statistically significant at $5 \%$ level. The coefficient indicated that for every additional year spent on poultry rearing brings about $35.21 \%$ of eggs output probably because of the knowledge the farmers' acquired over time through practice. Similarly, the coefficients of both family (0.0115) and hired labour (0.4364) were positive and significant at $1 \%$ and $5 \%$ probability levels. This showed that an increase in man-days of labour will bring about increase in the poultry eggs output by about $1.15 \%$ and $43.64 \%$ respectively. However, our results corroborate with the findings of Yusuf and Malomo (2007), Binuomote et al. (2008), Adeyemo (2009), Ashagidigbi et al. (2011),Tijjani et al. (2012), Jatto (2012), Onubuogu et al. (2014) and Esiobu et al. (2014) which indicated that poultry egg producers were relatively efficient in their production.

Table 1: Production Function Analysis of Poultry Egg Production

\begin{tabular}{lccc}
\hline Variable & Coefficients & Standard error & T-ratio \\
\hline Constant & 1.5292 & 0.3268 & $4.6800^{* * *}$ \\
Flock size (birds number) & 0.5794 & 0.0754 & $7.6789^{* * *}$ \\
Medication (\#) & 0.3005 & 0.0477 & $6.3048^{* * *}$ \\
Feeds (kg) & 0.3118 & 0.0499 & $6.2467^{* * *}$ \\
Hired labour (man-days) & 0.4364 & 0.1543 & $2.8288^{* * *}$ \\
Family labour(man days) & 0.0115 & 0.0058 & $1.9845^{* *}$ \\
Farmer's age (years) & -0.0495 & 0.0672 & $-0.7366^{\mathrm{NS}}$ \\
Experience (years) & 0.3521 & 0.1655 & $2.1273^{* *}$ \\
Water (liters) & 0.0333 & 0.0262 & $1.2717^{\mathrm{NS}}$ \\
Transportation cost (\#) & -0.0026 & 0.0037 & $-0.6892^{\mathrm{NS}}$ \\
$\mathrm{R}^{2}$ & 0.9633 & & \\
Adjusted R & 0.9592 & & \\
F-value & $236.08 * * *$ & \\
\hline
\end{tabular}

Source: Field Survey, 2016

Note: $* * *$ and $* *$ Represents $1 \%$ and $5 \%$ levels of significance

${ }^{\mathrm{NS}}$ represents insignificant variables

\section{Resource Use Efficiency}

In the marginal analysis of input utilization, marginal value product (MVP) and marginal factor cost (MFC) of each variable input was computed. MVP was calculated using the output of the regression analysis thereby considering the coefficient of each input $\left(\beta_{i}\right)$ and it corresponding market price. However, the market unit price of variable inputs such as day old chick, feeds and man-day of labour were used in order to compute the MFC. The unit price per day old chick was $\$ 200$, unit price of feed was $\$ 110 / \mathrm{kg}$ and labour was \#500 per man-day. 
Bajopas Volume 11 Number 1 June, 2018

The resource use efficiency of poultry egg production was determined by the ratio of MVP to MFC for each input (equation 2) as shown in Table 2. From the findings, it could be seen that the ratio for flock size $\left(X_{1}\right)$ was 3.19 which indicated that the said input was underutilized since the ratio obtained is greater than unity. This implies that additional number of birds per flock can enhance optimum resource utilization and consequently increase the profit level of the farmers. Further, the results revealed that feeds ratio $\left(X_{3}\right)$, was 192.64 which is also greater than unity implying that increasing the volume of feeds to the poultry birds can also enhance the profit level accruing to the farmers whereas in the case of hired labour $\left(X_{4}\right)$ and family labour $\left(X_{5}\right)$ the ratios were 0.0057 and 0.0729 respectively indicating that these resources were over utilized, since the ratio is less than unity. This implies that for the farmers to attain optimal efficiency level, the use of labour input has to be decreased as this could improve their profit level as well as their well-being. While a study on technical efficiency by Adepoju (2008), reported that operating expenses (Labor, drugs and transportation) were efficiently allocated and utilized, while the findings of Ala and Boniface (2009) revealed that inputs were under-utilized.

The results showed that poultry egg farmers in the study area are not efficient in their production as regards the four important resources (flock size, feeds, family and hired labour) that were used in this analysis. One important point to note is that of all the resources, none has a negative MVP signifying that these farmers are still producing within economically rational range. In a similar study by Nmadu et al. (2014), revealed that hired labour and family labour were over utilized. Likewise, the findings of Jongur et al. (2009) revealed that labour input with a value of 0.83 was over utilized, while flock size having scored 10.38 was under utilized.

Table 2: Marginal Analysis of Input Utilization of Poultry Egg Production

\begin{tabular}{lcccc}
\hline Resources & MVP & MFC & MVP/MFC & Resource utilization \\
\hline Flock size & 637.87 & 200 & 3.19 & Under utilization \\
Feed & $21,190.34$ & 110 & 192.64 & Under utilization \\
Familylabour & 2.84 & 500 & 0.0057 & Over utilization \\
Hired labour & 36.44 & 500 & 0.0729 & Over utilization \\
\hline
\end{tabular}

Source: Field survey, 2016

\section{CONCLUSION AND RECOMMENDATIONS}

This study analyzed resource use efficiency in poultry egg production in Yola North Local Government Area of Adamawa State, Nigeria. The findings revealed that farm inputs such as flock size, medication, feeds, family labour, hired labour and years of farming experience have positive and significant influence on poultry egg output, while farmers' age, transportation cost and volume of water intake does not influence poultry egg output in the study area. Moreover, marginal analysis of inputs utilization revealed that the farmers were not efficient in the use of their

\section{REFERENCES}

Adebayo, A. A and Tukur, A. L (1999). Adamawa State in Maps, Paraclete Publishers Yola, Nigeria: Pp 15-30.

Adebayo, C. O., Oseghale, A.I. and Adewumi, A. A. (2015). Profitability and Technical Efficiency among Broiler Farmers in Kwara State, Nigeria. Nigerian Journal of Agriculture, Food and Environment.11 (2): 92-96.

Adepoju, A. A. (2008). Technical Efficiency of Egg Production in Osun State, Nigeria. International Journal of Agricultural Economics and Rural Development.6 (8): 1-8

Adeyemo, A. A. (2009). Problems Militating Against Commercial Egg Production in Southern Guinea savannah of Nigerian. Proceeding of the Annual conference of Animal science of Nigeria September 14, 2009. LAU-TECH Ogbomoso, Nigeria Mp: 304.

Adeyemo, A. A. and Onikoyi, M. P. (2012). Prospects and Challenges of Large Scale resources based on the efficiency ratios obtained from flock size (3.19), feeds (192.64), family labour (0.0729) and hired labour (0.0057) variable inputs. Hence, productivity would be increased if farmers adopt a more effective and economic use of farm resources. In view of the above findings, the study recommends that poultry egg industry should be reorganized in such a way that labour input is used only for the necessary activities. Also, increasing the number of birds per flock and feeding rate of high quality can improve the resource use efficiency of the poultry egg farmers in the study area.

Commercial Poultry Production in Nigeria. Medwell Agricultural Journal. 7(6): 388-393.

Afolabi, C. A., Aladejebi, O. J. and Okejie, L. O. (2013). Analysis of Profitability and Constraints in Poultry Egg Farming under Battery cage and Deep litter Systems InOgun State, Nigeria: A Comparative Study. IJAFS .4(1\&2): 581-595.

Ahmed, M. A. and Egwuma, H. (2015). Assessing Economic Benefits of Cattle Fattening in Sardauna Local Government Area of Taraba State, Nigeria. International Journal of Innovative Research and Development. 4 (13): 353-358.

Ala, A. L. and Boniface, E. O. (2009). Economics of Commercial Poultry (layers) Production: A Case Study of some selected Firms in Sokoto Metropolis. Proceedings of the 23rd Annual National Conference of Farm Management Society of Nigeria: 14-17. Pp. 626-633. 
Alimi, T. (2000). Resource Use Efficiency in Food Crop Production in Oyo State, Nigeria. Journal of Agriculture and Environment.1 (1): 1-7.

Ashagidigbi, W. M., Sulaiman, S. A. and Adesiyan, A. (2011). Technical Efficiency of Egg Production in Osun State, Nigeria: International Journal of Agricultural Economics and Rural Development.4 (6): 4652.

Binuomote, S. O., Ajetomobi, J. O. and Ajao, A. O. (2008). Technical Efficiency of Poultry Egg Producers in Oyo State, Nigeria: International Journal of Poultry Science.7 (12):1227-1231.

Dama, L. H., Tashikalma, A. K. and Lawal, H. (2002). Resource Use Efficiency of Poultry Egg Production in Jos Plateau State, Nigeria: Bagale Journal of Pure and Applied Sciences.2 (2): 51-58.

Esiobu, N. S., Onubuogu., G. C. and Okoli, V. B. N. (2015). Determinants of Income from Poultry Egg Production in Imo State, Nigeria: An Econometric Model Approach. Global Advanced Research Journal of Agricultural Science. 3(5): 3-12.

FAOSTAT (2016). A database of the Food and Agriculture Organisation of the United Nations (FAO).www. fao.org

Farrel, M. J. (1957). The Measurement of Productive Efficiency. Journal of Royal Statistical Society: Series A Part 3:253-290.

Jatto, N. A., Maikasuwa, M. A., Jabo, S. and Gunu, U. I. (2012), Assessing the Technical Efficiency Level of Poultry Egg Producers in Ilorin Kwara State, Nigeria a Data Envelopment
Analysis Approach: European Scientific Journal.8 (27): 110-117.

Jongur, A. A. U., Oji, S. N., Yahaya, M. S. and Tashikalma, A. K. (2009). Profitability Analysis and Management Practices Among Poultry Farmers in Yola Metropolis of Adamawa State, Nigeria: Global Journal of Agricultural Sciences.8(2):237-343.

Ministry of Agriculture and National Resources (2008). MANR Annual Report.

Nmadu, J. N.,Ogidan, I. O. and Omolehin, R. A. (2014). Profitability and Resource Use Efficiency of Poultry Egg Production in Abuja, Nigeria: Kasetsart Journal of Social Sciences.35:134-146.

Nsikak-Abasi, A. E., Nse-Abasi, N. E., Edem, E. A. O. and Esther, U. E.(2013). Resource Use Efficiency in Small-Holder Poultry Egg Production in Rural Nigeria: Global Journal of Biology, Agriculture and Health Sciences.2 (3):146-149.

Onubuogu, G. C., Esiobu, N. S., Nwosu, C. S. and Okereke, C. N. (2014). Resource Use Efficiency of Smallholder Cassava Farmers in Owerri Agricultural Zone, Imo State, Nigeria. Scholarly Journal of Agricultural Science.7(8): 142-152.

Udoh, E. J. and Akintola, J. O. (2001). Measurement of the Technical Efficiency of Crop Farms in the South Eastern Region of Nigeria: Journal of Economics and Social Studies.43 (1): 93104.

Yusuf, S. A. and Malomo, O. (2007). Technical Efficiency of Poultry Egg Production Ogun State: A Data Envelopment Analysis (DEA) Approach. International Journal of Poultry Science.6 (9): 622-629. 